\title{
1,3-Dimethylimidazoyl-2-ylidene borane
}

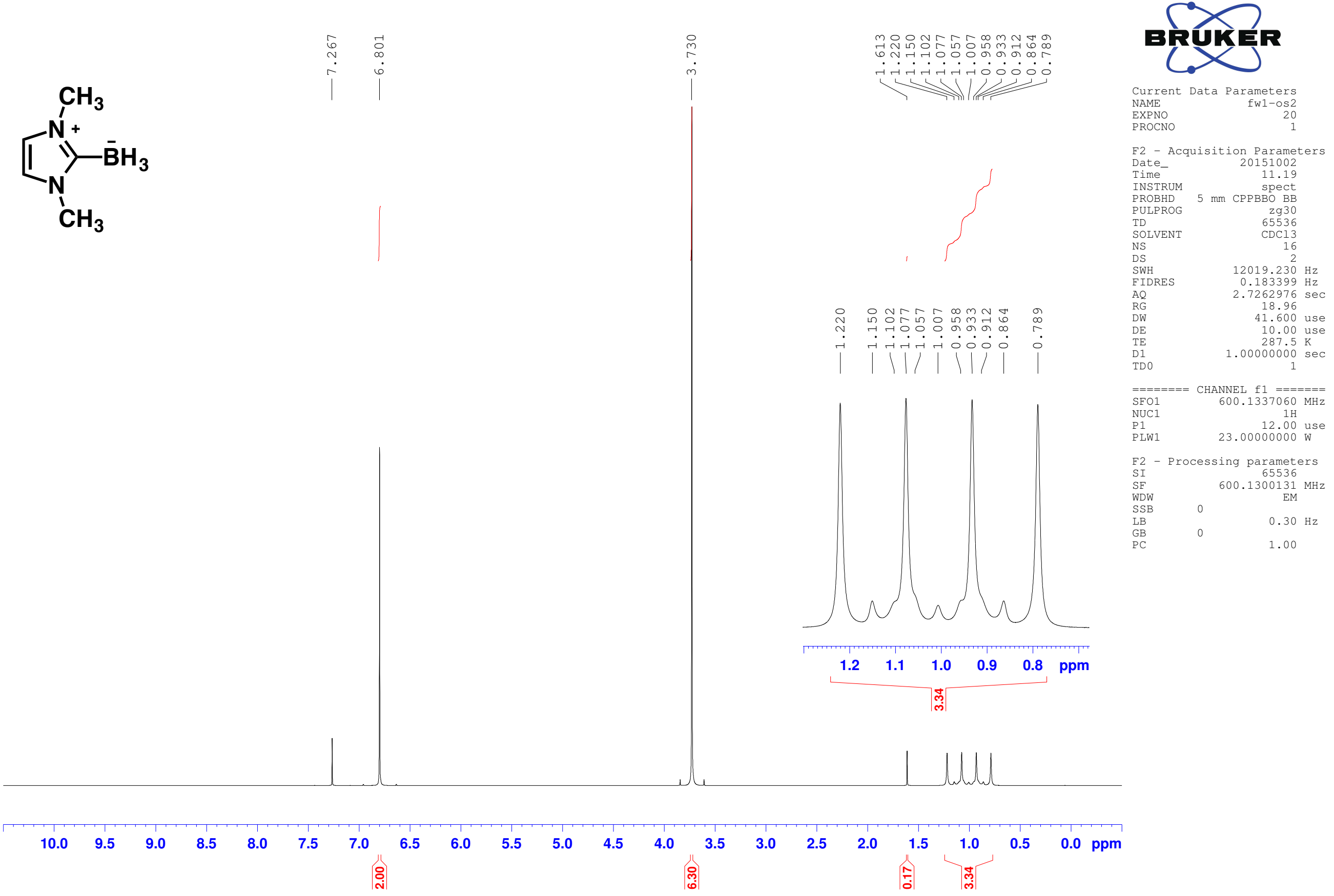

